Opinion

\title{
Food First: COVID-19 Outbreak and Cities Lockdown a Booster for a Wider Vision on Urban Agriculture
}

\author{
Giuseppe Pulighe *(D) and Flavio Lupia \\ CREA Research Centre for Agricultural Policies and Bioeconomy, Via Po 14, 00198 Rome, Italy; \\ flavio.lupia@crea.gov.it \\ * Correspondence: giuseppe.pulighe@crea.gov.it; Tel.: +39-06-4785-6814
}

Received: 15 May 2020; Accepted: 17 June 2020; Published: 19 June 2020

\begin{abstract}
The COVID-19 emergency has revealed the extreme fragility of large cities to unexpected complex global risks and crises. City lockdown has led to increasing awareness of the vital importance of food availability for citizens. The combined effect of border closure and movement restrictions increased food losses and export costs, especially for vegetables and perishable goods exposing non-self-sufficient countries. We claim the idea that urban agriculture in developed countries should be fostered with emerging growing practices and edible green infrastructures, such as vertical farming, hydroponics, aeroponic, aquaponic, and rooftop greenhouses. Notwithstanding the limitations of traditional urban farming activities, innovative and disruptive solutions and short food supply chains of fresh agricultural products might play a positive role in lessening uncertainties from global systemic risks.
\end{abstract}

Keywords: consumption habits; farming; food security; food supply; horticultural products; lockdown; resilience; zero-acreage farming

\section{Opinion}

The recently emerged coronavirus disease 2019 (COVID-19) pandemic has revealed the extreme fragility of large cities and citizens to unexpected complex global risks. Since the disease emerged in Wuhan city in China in January 2020, the international spread of severe acute respiratory syndrome (SARS-Cov-2) has caused over six million detected cases and over 371,000 deaths worldwide on 1 June 2020 [1], mostly urban dwellers. As the epidemic worsened, it has gradually emerged that cities had a low-risk perception and were poorly equipped to deal with the implications of imposed lockdown. Large and densely populated cities are sites of consumption, almost completely dependent on the outside resources for energy, water, materials and food flows. Moreover, these fluxes might be expected to worsen further if the projected global population living in urban areas grows to 6.3 billion people in 2050 [2].

City lockdown and business shut down have led to increasing awareness of the vital importance of the essential ecosystem goods and services that urban inhabitants benefit from, recognizing that food availability is one of the primary needs. Staple commodities' production and delivery are part of value web chains connecting farmers, industries, logistic, and final consumers in a globalized market. Although food supply and distribution systems are part of organized and profitable networks, the other side of the coin in developed countries are the well-documented postconsumer food losses and waste issues [3]. If globalization has so far ensured the movement of food products in the international market all over the world, the COVID-19 outbreak has brought emergent short-term effects on food supply and access.

At the global level, some countries have responded by taking measures to ensure national food security by blocking or restricting the export of several staple commodities. For instance, Russia, 
the world's biggest wheat exporter, has set limits on grain shipments to safeguard food reserves, while Kazakhstan, Serbia, and Vietnam set limits on exports of flour, sugar, potatoes, and sunflower oil [4]. Conversely, the European Union has eased its rules for vegetables and fresh fruit imports from India, accepting online certificates for assuring food safety and plant health standards [5]. As reported by FAO [6] in the World Food Situation, despite worries over impacts of COVID-19, the Food Price Index and global cereal markets are expected to remain balanced and financially stable, largely driven by demand contractions. Although supply lines of staple commodities seem to continue to function effectively without major concerns, social distancing interventions entail new processing methods, limitations for farmworkers, delay in harvesting, and dilated times in packaging, making it harder to produce and transport fresh food internationally. The combined effect is that border lockdown and movement restrictions increased food losses and export costs, especially for vegetables and perishable goods exposing non-self-sufficient countries [7].

At the city level, the mobility restrictions, social distancing measures, and shutdown of restaurants and public canteens introduced by governments and local administrators have impacted food consumption habits, food basket and diets that have changed rapidly. One of the first outcomes has been panic that induced people into a supermarket race on hoarding goods, especially long-lasting foods [8]. Results from a weekly consumer spending survey show that sales of edible goods, such as frozen foods, packaged foods, dairy products, and bottled water increased dramatically in Europe and the United States [9]. Interestingly, fresh food purchases increased in Germany $(+44.2 \%)$, UK $(+27.5 \%)$, Italy $(+9.8 \%)$, France $(+19 \%)$, and the USA $(+43.4 \%)$ in the week ending on 15 March 2020 , compared to the year-ago [10]. In the same week, looking at details regarding edible subcategories, top growing was registered for flours in Italy $(+185.9 \%)$ and France $(+253 \%)$, dried potato dumplings in Germany $(+241.9 \%)$, soup in the UK $(+206 \%)$, and yeast in the USA $(+501.5 \%)$. Similar significant uptick trends were observed in the USA, Italy, France, and Spain in e-commerce since the beginning of the crisis. In addition, home delivery services of food products and meals have registered positive trends on the purchase frequency, mainly online, and most users are likely to use it in the future post-pandemic [10].

The effect is that stocks of basic goods on the shelves have dropped, putting pressure on the supply chains, and in short term, retail prices have become more volatile, especially fresh vegetables and fruit. Though the preparation of meals at home can be seen as a resilient measure against the locked-down city, it is clear that low-income households, newly unemployed, and homeless people living on the margins are the most exposed to food insecurity with limited or uncertain access to enough food.

Notwithstanding these aspects, the pandemic will likely prompt governments and city authorities to consider redundancies and diversity of the global food system, regional self-sufficiency, and food security in cities more seriously [11]. Apart from global issues, in large cities, urban planning and food systems should be rethought with a new spatial arrangement and land management by fostering the resumption of food production with urban and peri-urban agriculture. Notably, there has been a surge in demand for urban allotments in developed countries in recent years [12], and it appears that the interest in self-production of fruits and vegetables has also grown during the COVID-19 pandemic [13].

Numerous studies have explored the potential of urban agriculture in terms of food security, dietary diversity, poverty alleviation, social inclusion, employment and income generation, resource circularity, and waste management [14]. Overall, motivations for urban gardening are generally driven by individual expectations and desires for healthy food, physical exercise, and mental relaxation [15]. The food production in urban areas falls within the context of edible green infrastructure and embraces the context of ecosystem services narrative with a spectrum of services and disservices [16]. Most of these studies relied on conventional outdoor farming (i.e., soil-based) and have raised questions about the real capacity of cities to become self-reliant in food, especially for protein and daily caloric intake [14]. At the same time, there is a need to better understand the relationships between urban agriculture and material and energy fluxes of cities, the "urban metabolism", to assess the real impacts on the environment from the diverse urban food production activities [17]. The key issue that emerged in the actual pandemic is whether it might be possible to effectively scale-up the urban farming to 
shorten food supply chains, reduce food-miles and food deserts to increase accessibility and resilience of urban production.

Findings from field-scale studies and reviews suggest that various forms of smart and innovative urban agriculture, such as vertical indoor farming, greenhouses, aquaponics, soil-less hydroponics, and aeroponics, result in high yields of horticultural products up to $140 \mathrm{~kg} / \mathrm{m}^{2} /$ year [18]. The most advanced systems can theoretically satisfy large strata of the population requirements of vegetable products (i.e., micronutrients and fiber) [18-20]. Innovative urban farms with climate control systems encompass high levels of technology, such as precision automation for nutrient dosing, light-emitting diode (LED) technology, artificial intelligence and blockchain, to optimize the growing process minimizing maintenance and costs [21]. In addition to production capacities, advanced indoor urban farms are less subject to natural disasters and weather-related problems [22], and may revitalize abandoned buildings, brownfield sites, and vacant spaces.

Overall, although most of the empirical case studies support the view that urban agriculture is highly productive and feasible to relieve some food insecurity issues $[19,23]$ and less susceptible to global changes, its scale-up to realistic production with sustainable business models poses many open questions touching aspects related to policy, economics, technology, logistics, and distribution [24]. Although urban agriculture is not the only possible solution to food security due to well-known limitations on space constraints for food self-provisioning $[25,26]$, we support the idea that fostering the production of fresh vegetables and fruits (highly volatile in price and perishable) may act as a resilient measure against food shortages by ensuring both balances with the urban resources and food safety. Again, the integration of innovative forms with traditional urban farming activities (preserving their social and environmental role) might overcome the mentioned limitations and offer a chance to achieve resource circularity, urban organic waste treatment, and water recycling.

Probably, in the future, with coordinated efforts of policymakers and planners, researchers, engineers, and agriculture practitioners, it would be possible to expand farming activities, to enable the integration in the urban landscape and to move toward a sustainable food system with safe and affordable fresh products and a synergistic management of urban and natural resources. Once the COVID-19 pandemic has passed, matching short food supply lines with local demand and consumer needs will be a great challenge to address for reducing uncertainties from global systemic risks and urban population growth. Although innovative farming deployment will not solve food security and dietary issues, it might contribute to shape a more resilient urban food system.

Author Contributions: Conceptualization, G.P. and F.L.; methodology, G.P. and F.L.; writing-original draft preparation, G.P. and F.L.; writing —-review and editing, G.P. and F.L.; funding acquisition, G.P. and F.L. All authors have read and agreed to the published version of the manuscript.

Funding: This research received no external funding.

Conflicts of Interest: The authors declare no conflict of interest.

\section{References}

1. WHO. Coronavirus Disease 2019 (COVID-19) Situation Report-133; WHO: Geneva, Switzerland, 2020.

2. ONU. World Urbanization Prospects: The 2018 Revision (ST/ESA/SER.A/420); United Nations Publications: New York, NY, USA, 2019; ISBN 9789211483192.

3. Chaboud, G.; Daviron, B. Food losses and waste: Navigating the inconsistencies. Glob. Food Sec. 2017, 12, 1-7. [CrossRef]

4. Russia Wants to Limit Grain Exports to Protect Food Supplies. Bloomberg. Available online: https://www. bloomberg.com/news/articles/2020-03-27/wheat-futures-rise-as-russia-considers-grain-export-quota (accessed on 16 April 2020).

5. COVID-19: EU relaxes fruit \& veggies imports; no orders from US. The Economic Times, 27 March 2020.

6. FAO. World Food Situation. Available online: http://www.fao.org/worldfoodsituation/foodpricesindex/en/ (accessed on 25 April 2020).

7. The coronavirus pandemic could threaten global food supply, UN warns. CNN, 12 April 2020. 
8. Coronavirus: The psychology of panic buying. BBC, 4 March 2020.

9. IRI. Consumer Spending Tracker for Measured Channels. U.S., UK, France, Italy, Germany, NZ; Information Resources Inc.: Chicago, IL, USA, 2020.

10. How COVID-19 Is Impacting Online Food Delivery Platforms. Citivelocity, 30 April 2020.

11. Puma, M.J.; Bose, S.; Chon, S.Y.; Cook, B.I. Assessing the evolving fragility of the global food system. Environ. Res. Lett. 2015, 10, 024007. [CrossRef]

12. Pulighe, G.; Lupia, F. Mapping spatial patterns of urban agriculture in Rome (Italy) using Google Earth and web-mapping services. Land Use Policy 2016, 59, 49-58. [CrossRef]

13. As gardeners turn to growing own food, research reveals dramatic decline in urban allotments over last 50 years. The Indipendent, 27 March 2020.

14. Badami, M.G.; Ramankutty, N. Urban agriculture and food security: A critique based on an assessment of urban land constraints. Glob. Food Sec. 2015, 4, 8-15. [CrossRef]

15. Ruggeri, G.; Mazzocchi, C.; Corsi, S. Urban gardeners' motivations in a Metropolitan city: The case of Milan. Sustainability 2016, 8, 1099. [CrossRef]

16. Russo, A.; Escobedo, F.J.; Cirella, G.T.; Zerbe, S. Edible green infrastructure: An approach and review of provisioning ecosystem services and disservices in urban environments. Agric. Ecosyst. Environ. 2017, 242, 53-66. [CrossRef]

17. Goldstein, B.; Hauschild, M.; Fernández, J.; Birkved, M. Urban versus conventional agriculture, taxonomy of resource profiles: A review. Agron. Sustain. Dev. 2016, 36, 9. [CrossRef]

18. Armanda, D.T.; Guinée, J.B.; Tukker, A. The second green revolution: Innovative urban agriculture's contribution to food security and sustainability-A review. Glob. Food Sec. 2019, 22, 13-24. [CrossRef]

19. McDougall, R.; Kristiansen, P.; Rader, R. Small-scale urban agriculture results in high yields but requires judicious management of inputs to achieve sustainability. Proc. Natl. Acad. Sci. USA 2019, 116, 129-134. [CrossRef] [PubMed]

20. Grewal, S.S.; Grewal, P.S. Can cities become self-reliant in food? Cities 2012, 29, 1-11. [CrossRef]

21. O'Sullivan, C.A.; Bonnett, G.D.; McIntyre, C.L.; Hochman, Z.; Wasson, A.P. Strategies to improve the productivity, product diversity and profitability of urban agriculture. Agric. Syst. 2019, 174, 133-144. [CrossRef]

22. O'Sullivan, C.A.; McIntyre, C.L.; Dry, I.B.; Hani, S.M.; Hochman, Z.; Bonnett, G.D. Vertical farms bear fruit. Nat. Biotechnol. 2020, 38, 160-162. [CrossRef] [PubMed]

23. Orsini, F.; Gasperi, D.; Marchetti, L.; Piovene, C.; Draghetti, S.; Ramazzotti, S.; Bazzocchi, G.; Gianquinto, G. Exploring the production capacity of rooftop gardens (RTGs) in urban agriculture: The potential impact on food and nutrition security, biodiversity and other ecosystem services in the city of Bologna. Food Secur. 2014, 6, 781-792. [CrossRef]

24. Weidner, T.; Yang, A.; Hamm, M.W. Consolidating the current knowledge on urban agriculture in productive urban food systems: Learnings, gaps and outlook. J. Clean. Prod. 2019, 209, 1637-1655. [CrossRef]

25. Mok, H.F.; Williamson, V.G.; Grove, J.R.; Burry, K.; Barker, S.F.; Hamilton, A.J. Strawberry fields forever? Urban agriculture in developed countries: A review. Agron. Sustain. Dev. 2014, 34, 21-43. [CrossRef]

26. Pulighe, G.; Lupia, F. Multitemporal Geospatial Evaluation of Urban Agriculture and (Non)-Sustainable Food Self-Provisioning in Milan, Italy. Sustainability 2019, 11, 1846. [CrossRef]

(C) 2020 by the authors. Licensee MDPI, Basel, Switzerland. This article is an open access article distributed under the terms and conditions of the Creative Commons Attribution (CC BY) license (http://creativecommons.org/licenses/by/4.0/). 